\title{
Response of biomass allocation strategies to plant-soil C:N:P stoichiometry in Alfalfa artificial grassland of different ages on the $\mathrm{Mu}$ Us Desert, China
}

\author{
zhouchang $\mathrm{yu}^{1}$, Wei Zhang ${ }^{2}$, Xiao-ping $\mathrm{Xin}^{3}$, yuanying $\mathrm{li}^{1}$, yi zhou ${ }^{4}$, ruirui $\mathrm{yan}^{5}$, zhiguo \\ xie $^{6}$, and Peizhi Yang ${ }^{1}$ \\ ${ }^{1}$ Northwest Agriculture and Forestry University \\ ${ }^{2}$ College of Agronomy \\ ${ }^{3}$ Chinese Academy of Agricultural Sciences \\ ${ }^{4}$ The University of Adelaide \\ ${ }^{5}$ Institute of Agricultural Resources and Regional Planning, Chinese Academy of \\ Agricultural Sciences \\ ${ }^{6}$ Shaanxi Academy of Forestry
}

August 20, 2020

\begin{abstract}
$\mathrm{C}: \mathrm{N}: \mathrm{P}$ stoichiometry is widely used in ecological research, but its role in the allocation of plant biomass is unclear. To explore this issue, we collected soil and alfalfa samples from 1, 2, 3, 5, 7, 9 and 10 year of alfalfa (Medicago sativa) plantations on the Mu Us Desert, China. We examined the aboveground and underground biomass of each plantation, the C, N, P contents, stoichiometric ratio of plants and soil, and soil biological characteristics. The $\mathrm{C}$ content of alfalfa increased first and then decreased with the growth age, which was opposite to $\mathrm{N}$ and $\mathrm{P}$ content, their most significant changes were in the 7-year stand. The individual changes of C-N-P in alfalfa led to the C:N and C:P increased first and then decreased, N:P increasing with the growth age. Soil OC, TN, C:P and N:P were increasing with the stand age, and TP content and C:N were increasing first and then decreasing. The $\mathrm{C}$ contents, $\mathrm{C}: \mathrm{P}$ and $\mathrm{N}: \mathrm{P}$ between alfalfa and soil were strongly correlated. N:P and underground biomass were positively correlated, while negatively correlated to aboveground. Our results show that the nutrient content and stoichiometric ratio in soil and plants were closely associated, after 7 years planting, the alfalfa's growth was limited by $\mathrm{P}$, it responds to the increased N:P by increasing root-shoot ratio, and soil fertility had also been improved at same time. Overall, these results provide a reference for further research on stoichiometry as an indicator to alfalfa yields on the Mu Us Desert.
\end{abstract}

Response of biomass allocation strategies to plant-soil C:N:P stoichiometry in Alfalfa artificial grassland of different ages on the Mu Us Desert, China

Zhouchang Yu

College of Grassland Agriculture, Northwest A\&F University, Yangling, 712100, Shaanxi, China Email:yuzhouchang@outlook.com2. Wei Zhang College of Grassland Agriculture, Northwest A\&F University, Yangling, 712100, Shaanxi, China Email: zwgwyd@163.com 3. Xiao-pin Xin National Hulunber Grassland Ecosystem Observation and Research Station Institute of Agricultural Resources and Regional Planning, Chinese Academy of Agricultural Sciences, Beijing 100081, China Email: xinxiaoping@caas.cn 4. Yuanying Li College of Grassland Agriculture, Northwest A\&F University, Yangling, 712100, Shaanxi, China Email: 931163407@qq.com5. Yi Zhou School of Agriculture, Food \& Wine, The University of Adelaide, Urrbrae, 5064, South Australia, 
Email: yi.zhou@adelaide.edu.au

6. Ruirui Yan

National Hulunber Grassland Ecosystem Observation and Research Station Institute of Agricultural Resources and Regional Planning, Chinese Academy of Agricultural Sciences, Beijing 100081, China Email: yanruirui@caas.cn7. Zhiguo Xie Shaanxi Academy of Forestry, Xi'an, 710082, Shaanxi, China Email: zhiguoxiesx@163.com

8. Peizhi Yang (Corresponding author)

College of Grassland Agriculture, Northwest A\&F University, Yangling, 712100, Shaanxi, China Email: yangpeizhi@126.com

Abstract

$\mathrm{C}: \mathrm{N}: \mathrm{P}$ stoichiometry is widely used in ecological research, but its role in the allocation of plant biomass is unclear. To explore this issue, we collected soil and alfalfa samples from 1, 2, 3, 5, 7, 9 and 10 year of alfalfa (Medicago sativa) plantations on the $\mathrm{Mu}$ Us Desert, China. We examined the aboveground and underground biomass of each plantation, the C, N, P contents, stoichiometric ratio of plants and soil, and soil biological characteristics. The $\mathrm{C}$ content of alfalfa increased first and then decreased with the growth age, which was opposite to $\mathrm{N}$ and $\mathrm{P}$ content, their most significant changes were in the 7-year stand. The individual changes of C-N-P in alfalfa led to the C:N and C:P increased first and then decreased, N:P increasing with the growth age. Soil OC, TN, C:P and N:P were increasing with the stand age, and TP content and C:N were increasing first and then decreasing. The C contents, C:P and N:P between alfalfa and soil were strongly correlated. $\mathrm{N}: \mathrm{P}$ and underground biomass were positively correlated, while negatively correlated to aboveground. Our results show that the nutrient content and stoichiometric ratio in soil and plants were closely associated, after 7 years planting, the alfalfa's growth was limited by $\mathrm{P}$, it responds to the increased N:P by increasing root-shoot ratio, and soil fertility had also been improved at same time. Overall, these results provide a reference for further research on stoichiometry as an indicator to alfalfa yields on the Mu Us Desert.

Keywords :P-limitation; stoichiometry; aboveground; underground; root-shoot ratio

\section{Introduction}

In agricultural production, there is a certain interaction between soil and plants. Soil provides carbon (C), nitrogen $(\mathrm{N})$, phosphorus $(\mathrm{P})$ and other nutrients for plant growth, and the growth and development of plants will influence the soil property by the return of litter (Bermejo et al., 2020, Oo et al., 2020), the discharge of root exudates (Masikane et al., 2020, Wang et al., 2020) and the maintenance of soil and water (Li et al., 2011, Abinandan et al., 2019, Vezzani et al., 2018). But how to use the stoichiometry of plants and soil as an indicator in agricultural production to improve crop yields has been rarely studied.

Firstly, the C:N:P stoichiometry changes in different environments and geographic regions. In the Tibet region of China, the contents of $\mathrm{C}, \mathrm{N}, \mathrm{P}$ in alpine steppe soil are significantly different from alpine meadow, and the ratio of C:N, C:P and N:P in steppe soil is higher (Chen et al., 2016b). Moreover, the N:P ratio of plants in China was significantly higher than the global average level caused by a greater shortage of soil $\mathrm{P}$ in China (Han et al., 2005). Studies conducted in the forests of Catalonia found that with the increase of latitude and precipitation, the nutrient content of the leaves increased, and the ratio of C:N in the leaves decreased, and the leaves of plants growing in the youngest soil have the lowest N:P, supporting the Soil-Age Hypothesis (Sardans et al., 2011a). Secondly, even in the same area, the stoichiometric ratio between plants and soil is also influenced by plant species. It has been found that in various regions of the world non-legume plant communities had higher soil C:N, C:P and N:P ratios, but lower leaf N:P ratio than legumes (McGroddy et al., 2004b, Reich et al., 2004, Yang et al., 2018). In addition, the stand age or lifespan of plants also affects the stoichiometry of plants and soil. in the forest ecosystem, the C:N ratio in the tree increases with 
the planting age, while the C:N ratio in litter, forest floor and mineral soil have no significant change with the stand age (Hooker \& Compton, 2003, Yang \& Luo, 2011b, Bai et al., 2019). The N:P ratio of plants is often used to reveal growth-limiting elements (Gusewell, 2004), e.g. N:P $>16$ indicates that plant growth is restricted by $\mathrm{P}$, and $\mathrm{N}: \mathrm{P}<14$ indicates that plant growth is restricted by $\mathrm{N}$ (Reich \& Oleksyn, 2004b). This conclusion has been widely recognized, but it is unclear whether it can be used in the cultivation of perennial grass perennial forage alfalfa, because the cutting effect in alfalfa management might affect litter return and the C:N:P stoichiometry.

Alfalfa, as a high-yield forage, has continuously regenerating and rapidly growing leaves during the growing season (Alegre et al., 2004). The age of alfalfa and harvesting times can significantly affect the N: P of alfalfa leaves, and the N, P content of alfalfa leaves has a negative correlation with N: P (Wang et al., 2015, Wang et al., 2014). Zhang et al. (2013). indicated that the N:P ratio of alfalfa generally decreases first and then increases with stand age. The greenhouse experiments showed that increasing the water supply can ameliorate the restriction of soil P limitation (Lu et al., 2019), both studies used the alfalfa N:P ratio indicating element limitation, while with the effect of alfalfa planting age on nutrient restrictions and limitation factors of growth is still unknown.

The objective of this study was to find out the relationship between the aboveground-underground biomass distribution changes of alfalfa and C:N:P stoichiometry under Mu Us Desert ecosystem. We selected 1, 2, 3, 5, 7, 9 and 10 year of alfalfa plantations from Yulin, Shaanxi, China, to collect alfalfa and soil samples. The area is all sandy soil with uniform climate and agricultural management, which provides good conditions for the experiment. Our aims were to evaluate (1) how the stoichiometric ratio of alfalfa and soil changes with stand age; (2) the relationship between alfalfa and soil stoichiometric ratio; (3) the alfalfa biomass allocation strategy to C:N:P stoichiometry.

\section{2. materials and methods}

\subsection{The study area and experimental design}

The field experiment was conducted in the Yuyang District of Yulin City, Shaanxi Province, China (Fig. 1). The area belongs to semi-arid continental monsoon climate with an average elevation of 1000-1200 meters, annual average precipitation is $365.7 \mathrm{~mm}$ (Most occurs in July and August), annual average temperature of $10.7^{\circ} \mathrm{C}$ (monthly average temperature range is $-13-29^{\circ} \mathrm{C}$ ). The soil is a sandy loam with $66 \%$ silt and $32 \%$ clay, representing the local farmland soil. The landforms are mostly semi-fixed and fixed sand dunes, and the ecological environment is fragile due to the relatively barren soil and simple species structure.

Our study started in July 2019, according to field investigations and local government documents on alfalfa cultivation, 24 sites with similar geographical features and soil types, were selected as experimental plots, including seven age groups $(1,2,3,5,7,9$ and 10 years) of the alfalfa with 3 sites per age group and 3 maize (Zea mays) farmland (FL) as the control. Before the establishment of alfalfa, maize and potatoes (Solanum

tuberosum ) were mainly grown in this area. Sites of different stand ages are more than $2 \mathrm{~km}$ apart, and 3 repeated sites of the same stand age are more than $1 \mathrm{~km}$ apart. Three plots $(20 \times 20 \mathrm{~m})$ from each site were randomly selected for investigation and sampling, and the average measures of three replicated plots in the same site was used as the observation.

\subsection{Plant and soil samplings}

We selected five $1 \mathrm{~m} \times 1 \mathrm{~m}$ squares according to the five-point sampling method in each plot. All soil and plant samples were collected in squares, and represent each plot after fully mixed. All age groups were sampled at the early flowering stages of alfalfa in July and August, 2019. And 72 samples were collected (eight age group $\mathrm{x}$ three sites per age group $\mathrm{x}$ three replicate plots per site). 
We used a $4 \mathrm{~cm}$ diameter soil drill to collect 0-10 $\mathrm{cm}$ soil in each square, and removed the plant roots and stones. Samples were divided into two parts after homogenization, a part of the soil sample was air-dried for the chemical property measurements and the other part was stored in the refrigerator (about 4degC). Then soil enzyme activity and microbial biomass were measured within 1 week. Aboveground and underground biomass of alfalfa has been investigated in each square. Plants were cut to ground-level, meanwhile, root system was sampled by a root drill $(10 \mathrm{~cm}$ diameter $)$ to take $0-100 \mathrm{~cm}$ depth of the soil profile. Then the samples were taken back to lab, rinse with water and oven-dried for $10 \mathrm{~min}$ at $105 \mathrm{degC}$ and then at $65 \mathrm{degC}$ for 72 hours, and weighed.

\subsection{Measurements and calculations}

Total C (TC) in the plant and soil was measured by the organic element analyzer (elementar vario MACRO cube, Elementar, Germany). Soil organic C (SOC) was measured using the potassium dichromate/sulfuric acid mixture titration method. Total $\mathrm{N}(\mathrm{TN})$ in the plant and soil was measured using the semimicroKjeldahl method with a Kjeldahl auto-analyzer (KjeltecTM 8400, FOSS, Denmark). Alkaline hydrolysis diffusion method was used to determine soil alkali nitrogen (AN). Total P (TP) in the plant and soil was measured by a spectrophotometer (UV-2450, Shimadzu, Japan). Soil available P (AP) was extracted in 0.5 mol${ }^{*} \mathrm{~L}^{-1} \mathrm{NaHCO}_{3}$ and the concentration was determined using the Olsen method. Soil available K (AK) was extracted in $1 \mathrm{~mol}^{*} \mathrm{~L}^{-1} \mathrm{CH}_{3} \mathrm{COONH}_{4}$, and measured by Atomic Abserption Spectrometer (PinAAciie 900F, PE, US).

The C:N:P stoichiometric ratios of plant were calculated as TC vs. TN (C:N), TC vs. TP (C:P) and TN vs. TP (N:P). As for stoichiometric ratios in the soil, they were calculated as OC vs. TN (C:N), OC vs. TP $(\mathrm{C}: \mathrm{P})$ and $\mathrm{TN}$ vs. TP $(\mathrm{N}: \mathrm{P})$.

The determination method of soil urease was based on phenol-sodium hypochlorite sodium colorimetry, the $0.1 \mathrm{~N} \mathrm{KMnO}_{4}$ titration method was used to measure soil catalase activity and invertase was measured by 3,5Dinitrosalicylic acid colorimetry (Xiao et al., 2018, Zhen et al., 2018). Soil microbial biomass C (MBC) was measured by Total Organic Carbon Analyzer (TOC-VCPH, Shimadzu, Japan) after chloroform fumigation and $0.5 \mathrm{~mol}^{*} \mathrm{~L}^{-1}$ potassium-sulfate extracted. Soil microbial biomass N (MBN) was measured by auto-analyzer (Auto Analyzer 3-AA3, SEAL, US) after chloroform fumigation and $0.5 \mathrm{~mol}^{*} \mathrm{~L}^{-1}$ potassium-sulfate extracted.

\subsection{Statistical analysis}

Analysis of the differences in element concentrations and their stoichiometric ratios in all age groups were using ANOVAs and least significant difference (LSD) multiple comparison $(P<0.05)$. The linear correlations of $\mathrm{C}, \mathrm{N}, \mathrm{P}$ concentrations and stoichiometric ratio were analyzed with the model $y=a x+b$. The correlation coefficient of aboveground and underground biomass with C, N, P content and stoichiometric ratio was calculated by Person correlation analysis.

\section{Result}

\subsection{Alfalfa C, N, P concentrations and stoichiometric ratio in differently age groups}

The C, N and P concentrations of alfalfa were significantly affected by stand age (Fig. 2I, II, and III). The variation of the $\mathrm{C}$ content in the alfalfa fluctuated slightly from different age groups, with an average value of $453.0 \mathrm{~g}^{*} \mathrm{~kg}^{-1}$, and the fluctuations did not exceed $4.7 \%$. The change trend of $\mathrm{C}$ content was to increased first and then decreased, with significant maximum and minimum values in 7-year stand and 1-year stand, respectively. The $\mathrm{N}$ content in the plant varies from $28.6-45.7 \mathrm{~g}^{*} \mathrm{~kg}^{-1}$, but there was no obvious trend in the change of alfalfa $\mathrm{N}$ concentration among in various years, and the minimum value was in 7-year stand, the 
maximum was in 10-year. P content decreased from $4.0 \mathrm{~g}^{*} \mathrm{~kg}^{-1}$ to $1.9 \mathrm{~g}^{*} \mathrm{~kg}^{-1}$ between 1-year to 7 -year stand, but increased to $2.5 \mathrm{~g}^{*} \mathrm{~kg}^{-1}$ in 9-year and 10-year stands.

The changes of alfalfa C:N, C:P and N:P were significantly related to stand age (Fig. 2IV, V, and VI). Alfalfa C:N and C:P had similar trend, and they all increased and then decreased with stand age. C:N had a significant highest value in 7-year stand and the lowest in 10-year stand. The 7-year stand also had the highest value of $\mathrm{C}: \mathrm{P}$, but the lowest $\mathrm{C}: \mathrm{P}$ in the 1-year stand. The $\mathrm{N}: \mathrm{P}$ ratios of alfalfa was positively correlated with the stand age $(P<0.01)$, and there was over double increase in 10 -year stand.

\subsection{Soil OC, TN and TP concentrations and stoichiometric ratio in differently age groups}

Soil OC was affected significantly by alfalfa stand age (Fig. 3I). The OC in the first two years was lower than $2.4 \mathrm{~g}^{*} \mathrm{~kg}^{-1}$ of the FL, but it was increased with stand age. The significant maximum value of OC was 9.62 $\mathrm{g}^{*} \mathrm{~kg}^{-1}$, appeared in 9-year stand. Soil TN was also significantly affected by the stand age (Fig. 3II), but the TN content were $0.12-0.23 \mathrm{~g}^{*} \mathrm{~kg}^{-1}$ in 1-3 year stands, there was no obvious difference compared with the FL. There was a significant increase in 7-10 years, an increase of 4.5-7 times relative to the FL. The maximum TN appeared in 10-year stand and was significantly higher than other age groups. The fluctuation of soil TP was not as obvious as the SOC and soil TN (Fig. 3III), only in the 1-year, 9-year and 10-year stands had a significant increase, other age groups had no significant increase compared with the FL of $0.5 \mathrm{~g}^{*} \mathrm{~kg}^{-1}$, and the maximum TP content appeared in 9-year stand, higher by $50.0 \%$ then FL.

Soil C:N was significantly reduced by the cultivation of alfalfa compared to the FL (Fig. 3IV). The first year of alfalfa planting fell by $45.1 \%$, which was to the greatest extent. Then C:N started to rise, but it was always 16.7-34.0\% lower than FL, and the maximum C:N appeared in 3-year stand in all alfalfa plantation. Soil $\mathrm{C}: \mathrm{P}$ was slightly lower than the FL in the first two age groups, and then increased with stand age (Fig. 3V), The maximum C:P appeared in 10-year stand, which was 2.8 times of FL. Soil N:P ratio was significantly correlated with alfalfa stand age (Fig. 3VI). The soil N:P of all year stands were higher than FL, but it did not increase significantly except 5-10 year stands. The change trend of N:P was similar to the C:P, increased with stand age. The maximum value of C:P appeared in 10-year stand, was 4.9 times higher compared to the FL.

\subsection{Relationships between alfalfa growth and soil stoichiometry}

Alfalfa biomass was significant affected by growth age (Fig. 4I). It increased first and then decreases, with the largest biomass in the 2-year stand, the smallest in the 10-year stand, and the maximum value is $287.3 \%$ higher than the minimum value. Underground biomass generally increased with growth age (Fig. 4II), but the relatively higher in 1-year stand may be due to more weed roots in the newly established plantation of alfalfa. Therefore, it led to a root-shoot ratio of similar trends (Fig. 4III).

The biomass of alfalfa was negatively correlated to alfalfa $\mathrm{N}\left(\mathrm{R}^{2}=0.19, \mathrm{P}<0.05\right)$ and positively related to alfalfa $\mathrm{P}\left(\mathrm{R}^{2}=0.26, \mathrm{P}=0.02\right)$ (Fig. $\mathrm{S} 1 \mathrm{~V}$ and $\left.\mathrm{VI}\right)$, so there were negatively related between alfalfa biomass and alfalfa $\mathrm{C}: \mathrm{P}$ and N:P (Fig. 5). Underground biomass was negatively related to alfalfa $\mathrm{P}\left(\mathrm{R}^{2}=0.43, \mathrm{P}<0.01\right)$ (Fig. S2VI) and positively related to alfalfa C:P and N:P (Fig. 5). The root-shoot ratio was positively related to alfalfa $\mathrm{N}\left(\mathrm{R}^{2}=0.27, \mathrm{P}=0.02\right)$ (Fig. $\left.\mathrm{S} 3 \mathrm{~V}\right)$, while negatively related to alfalfa $\mathrm{P}\left(\mathrm{R}^{2}=0.25, \mathrm{P}=0.02\right)$ (Fig. S3VI), thus there was a positively correlation between root-shoot ratio and alfalfa N:P (Fig. 5).

The biomass of alfalfa was negatively related to soil $\mathrm{OC}\left(\mathrm{R}^{2}=0.70, \mathrm{P}<0.01\right)$, TN $\left(\mathrm{R}^{2}=0.81, \mathrm{P}<0.01\right)$, TP $\left(\mathrm{R}^{2}=0.42, \mathrm{P}<0.01\right)$ (Fig. S1I, II and III), soil $\mathrm{C}: \mathrm{P}$ ratio and soil $\mathrm{N}: \mathrm{P}$ (Fig. 5). While underground biomass was positively related to soil $\mathrm{OC}\left(\mathrm{R}^{2}=0.65, \mathrm{P}<0.01\right)$, $\mathrm{TN}\left(\mathrm{R}^{2}=0.69, \mathrm{P}<0.01\right)$, $\mathrm{TP}\left(\mathrm{R}^{2}=0.34, \mathrm{P}<0.01\right)$ (Fig. S2I, II and III), soil C:P ratio and soil N:P (Fig. 5). So it can be easily inferred that the root-shoot ratio was also significantly positively correlated with soil $\mathrm{OC}\left(\mathrm{R}^{2}=0.75, \mathrm{P}<0.01\right)$, $\mathrm{TN}\left(\mathrm{R}^{2}=0.82, \mathrm{P}<0.01\right)$, TP $\left(\mathrm{R}^{2}=0.43, \mathrm{P}<0.01\right)$ (Fig. S3I, II and III), soil C:P ratio and soil N:P (Fig. 5). 
The redundancy analysis in our article revealed the C, N, P, stoichiometric relationship between alfalfa and soil. The results showed that during the growth of alfalfa, the content of nutrient elements in the soil would be significantly affected by the $\mathrm{C}, \mathrm{N}, \mathrm{P}$ and stoichiometric ratio of alfalfa (the together explain value of total variation was 50.86\%), alfalfa TP and $\mathrm{N}: \mathrm{P}$ have the most significant influence (Fig. 6). Soil OC and alfalfa $\mathrm{C}$ content have a significant positive correlation, but $\mathrm{N}$ and $\mathrm{P}$ had no significant correlation between soil and alfalfa. The C:P and N:P ratios have significant positive correlation between soil and alfalfa (Fig. 6).

\section{DISCUSSION}

\subsection{The C:N:P characteristics of soil and alfalfa}

In our study, the change of SOC content was not obvious in 1-5 year stands, and even has a downward trend, but significantly increased in 7-9 year stands (Fig. 3I). Soil C in traditional farmland was found to have a similar trend (Jones et al., 2012, Li et al., 2011, Fiorini et al., 2020), while it was different with the increasing trend of organic C in forest or other species stand (Paul et al., 2002, Chang et al., 2014, Zhiyanski et al., 2016, Guo et al., 2020). A possible explanation is that alfalfa as a perennial leguminous forage was managed with the 3-4 times mowing per year, thereby, the decomposition rate of soil $\mathrm{C}$ has exceeded the rate of sequestration from litter and rhizome deposition (Vesterdal et al., 2002). As for the accumulation of SOC in 7-10 year stands, it can be attributed to the decrease in alfalfa biomass at the old-age period (Fig. $4 \mathrm{I}$ ), so the OC taken away from the soil by mowing would decrease too. In addition, as the planting age of alfalfa increases, the increase of recalcitrant litter and organic matter in the soil would also enhance the C accumulation (Paul et al., 2003, Kubar et al., 2019, Li et al., 2019). The change of soil N content with planting age was similar to SOC. Due to the decrease of alfalfa's absorption of soil C and N and nitrogenfixation by root system (Yang et al., 2011a, Griesmann et al., 2018), the TN and AN content of the soil increased significantly in 7-10 year stands (Fig. 3II, Tables S1), which led the downward trend of C:N in 7-10 year stands (Fig. 3IV). The soil TP content did not fluctuate greatly in alfalfa planting stands, only increased in 9 and 10 year stands but was far less than the increase of $\mathrm{C}$ and $\mathrm{N}$, so soil $\mathrm{C}$ : $\mathrm{P}$ and $\mathrm{N}$ : $\mathrm{P}$ ratios significantly increased in the 7-10 year stands (Fig. 3). This phenomenon is similar to previous studies (Wang et al., 2015), it probably due to the deep root system of alfalfa that brings mineral elements such as phosphorus to the top soil or the consequently weakness of P absorption (Li et al., 2011).

Alfalfa C, N and C:N were affected significantly by stand age in our study (Fig. 2I, II and IV). But the C:N ratio change of legumes was not like forest trees (Zhang et al., 2019a). The C:N ratio of woody plants would increase with growth age due to the increased proportion of xylem (Yang \& Luo, 2011b, Zhang et al., 2019b). In our study, alfalfa C:N peaked at 7-year and then declined (Fig. 2IV). As a perennial legume, we harvest the branches and leaves of alfalfa, so that it was often in a status of regeneration, unable accumulate $\mathrm{C}$ as much as the wooden species. The $\mathrm{C}$ content does not have large fluctuation in different age groups, but the $\mathrm{N}$ content has increased significantly in 7-10 year stands, which resulting in a decrease in C:N content (Fig. 2). The $\mathrm{P}$ content decreased first and then increased with the alfalfa planting age (Fig. 2III), so it was understandable that the C:P ratio had the opposite trend, and the maximum value in 7-year stand (Fig. 2V), same with the C:N ratio. Thus, it suggested that at after 7 years, the growth of alfalfa was restricted, and the ability of plants to absorb soil $\mathrm{P}$ decreased. The content of TN and TP changes very similar in alfalfa, and both are significantly affected by stand age. $\mathrm{N}$ and $\mathrm{P}$ of plants were very active in metabolism, sensitively affected by plantation years (Wang et al., 2014) and other non-biological factors (Reich \& Oleksyn, 2004b, Sardans et al., 2011b, Song et al., 2020). Similarly to previous research, the P content in plant leaves would decrease with the growth age (Fan et al., 2015a, Elser et al., 2010, Wang \& Zheng, 2020) (Fig.2 III). The N:P ratio of alfalfa was negatively correlated with P content (Tables S2), which was consistent with studies in Molinia caerulea, Carex flava (Gusewell, 2004) and Tibetan Plateau meadow (Hong et al., 2014). Plant N:P ratios are often used to reveal element limitations in ecosystems, generally believed that $14<\mathrm{N}: \mathrm{P}<16$ is suitable for plant growth (Reich \& Oleksyn, 2004a). However, different species may have different N:P thresholds. Braakhekke et al. (1999) measured the data of 74 grassland plots and 
found that when grassland plant $\mathrm{N}: \mathrm{P}<10$, their growth was mainly restricted by $\mathrm{N}$, and when $\mathrm{N}: \mathrm{P}>14$, their growth was mainly restricted by P. Considering that alfalfa is a grass plant, so according to this report, we can clearly see that the growth of alfalfa in the 1-year stand and 2-year stand was mainly restricted by $\mathrm{N}$, and from the 5 th year and after, it was restricted by P (Fig. 2VI).

\subsection{The interaction between alfalfa growth and soil stoichiometry.}

Both $\mathrm{N}$ and $\mathrm{P}$ in alfalfa come from soil, so the changes of $\mathrm{N}$ and $\mathrm{P}$ in the soil will definitely affect the stoichiometric ratio in the alfalfa (Fig. 6), which verify previous research (McGroddy et al., 2004a, Yang \& Luo, 2011b, Liao et al., 2014, Xie et al., 2020). The C:N ratio of alfalfa had increased significantly in the 7-year stand, because the $\mathrm{N}$ content in the alfalfa has decreased (Fig. 2). But the $\mathrm{N}$ content in the soil has increased significantly at the meantime (Fig. 3II). The reason for this may be that the plant's biological nitrogen-fixing ability was weakened when it grew to a certain age (Jacobs et al., 2007, Lynd \& Ansman, 1993) (McKenzie \& McLean, 1984, Hwangl \& Flores, 1987), so that a large amount of $N$ cannot be transported into plant for its growth and development, but stayed in the soil. Then, the accumulation of $\mathrm{N}$ would accelerate root growth (Kou et al., 2019) (Fig. 4II). The accompanying decrease in the aboveground biomass of alfalfa in the 7-year stand (Fig. 4I) also illustrates its problem of growth limitation.

The C:P ratio of soil to alfalfa was closely related in this study (Fig. 6), and the C:P ratio in plants can indicate the efficiency of $\mathrm{P}$ use, symbolizing the absorption balance of $\mathrm{C}$ and $\mathrm{P}$ from soil into plants (Schindler, 2003), so the change of plant C:P ratio was caused by at least one of soil OC or TP. In our study, the plant C:P ratio was positively correlated with SOC (Tables S2). So, the C:P ratio of alfalfa was affected heavily by OC than TP, this was inconsistent with previous research results (Wang et al., 2015), the possible reason is that in the $\mathrm{Mu}$ Us Desert area, the soil $\mathrm{P}$ content is too scarce. In fact, that alfalfa cultivation had little effect on the TP content in the soil, only a slight increase in 9-year and 10-year stands (Fig. 3III).

The N:P ratio in soil and alfalfa was closely related (Fig. 6), however, the increase of $\mathrm{N}$ content in the soil did not directly affect the $\mathrm{N}$ content of alfalfa (Fig. 6). Cui et al. (2010) indicated that the $\mathrm{N}$ supplement in the soil would increase the $\mathrm{N}$ content in the plant leaves, which was inconsistent with us, probably reason is that the increase of $\mathrm{N}$ content in the our alfalfa stands mainly comes from the biological nitrogen fixation of alfalfa instead of the artificial $\mathrm{N}$ fertilizer in Cui's research. But the increase of $\mathrm{N}$ content in the soil was significantly positively related to the N:P ratio of alfalfa (Tables S2). Plant N:P ratios can reflect their growth rate, Agren's (2004) research shows that plants with higher growth rates had lower N:P ratios because higher growth rates require more rRNA, DNA and ATP etc. input to produce the phosphorus-containing compounds needed for growth (Fan et al., 2015b, LeBauer \& Treseder, 2008, Ren et al., 2016), while they was a major P-bank of plants, therefore, an increase in phosphorus-containing compounds content would result in a disproportionate increase in $\mathrm{P}$ concentration in plant cells, thereby reducing the $\mathrm{N}: \mathrm{P}$ ratio. The same phenomenon was found in our research. And as the alfalfa stands age increases, the N:P ratio had been increasing (Fig. 2VI), consistent with the report by Wang et al (Wang et al., 2014, Wang et al., 2015). The growth rate of alfalfa affects its yields, thus we find that its yields was significantly negatively correlated with the N:P ratio (Fig. 5), and there would be the maximum yield in the third year (Fig. 4I).

Our research also shows that the N:P ratio of soil and plants was positively correlated with root-shoot ratio (Fig. 5). In the early stage of alfalfa growth, due to the rapid growth of underground root system, the $\mathrm{P}$ content in alfalfa increased rapidly and resulting in a lower N:P ratio (Fig.2III and VI). With the growth of alfalfa, it needs more nutrients (OC, TN, TP) supplied by the soil (Fig. 3I, II and III). So, plant would product more and deeper root systems to cope with this situation (Fig. 4II). Kou's (2019) research also said that the addition of $\mathrm{N}$ (similarly with the increase of $\mathrm{N}$ in 7-10 years, Fig. 3II) in P-limited soil would increase the root production. The formation of equal weight roots consumes more photosynthetic products, therefore, the prosperity of the root system would lead to a decline in aboveground production in nutrient limited ecosystems (Gersani et al., 2001, Laird \& Aarssen, 2005, Ma et al., 2010, Maina et al., 2002), nutrient resorption from senescing leaves and stems can reduce the loss of nutrients inside the plant and to less depend on soil nutrients (Sohrt et al., 2018). But the available P content was mainly concentrated in the surface 
layer of the soil (Li et al., 2020, Barbosa et al., 2015, Cassagne et al., 2000). Therefore, the content of P in alfalfa did not increase with the growth of age, and the content of $\mathrm{P}$ and $\mathrm{AP}$ in the upper soil did not decrease significantly or even increased in 9-year and 10-year stands (Tables S1) due to the return of plant litter (Chen et al., 2016a, Liu et al., 2020), but it was not obvious compared with the increase of soil N content. Consequently, if we want to improve this situation through artificial fertilization, we should increase the proportion of $\mathrm{P}$ fertilizer used, and fertilize in deep soil.

We found that the N:P ratio of alfalfa was significantly related to soil microbial biomass C, N (Tables S2). In agricultural management, microbial biomass $\mathrm{C}$ and $\mathrm{N}$ are used as early indicators of nutrient cycling and organic matter dynamics in the soil (Xiao et al., 2018, Joergensen et al., 1995). In 7-year stand, the microbial biomass $\mathrm{C}$ and $\mathrm{N}$ had decreased significantly, and the growth of alfalfa was limited, which indicating that this area was no longer suitable for alfalfa cultivation at this time. Alfalfa aboveground biomass is negatively correlated with soil nutrients (Fig S1I,II and III), after 7 years of planting, although the growth of alfalfa continued to deteriorate, soil nutrient content (Tables S1), microbial biomass C, N and soil enzyme activity began to rose (Tables S3), all of those characteristics were significantly higher than FL. These phenomena mainly come from the growth of legumes, the return of litter, the increase of soil microbial communities, the decomposition of soil minerals and organic matter are all its functions (Iqbal et al., 2019, Kohmann et al., 2018). In summary, with the age of cultivation, alfalfa responds to more and more severe $\mathrm{P}$ restrictions by changing the allocation of aboveground and underground biomass, meanwhile increase the soil nutrient content, enzyme activity and microbial biomass, which make the soil more suitable for vegetation growth or agricultural production (Boerner et al., 2005).

\section{CONCLUSION}

Significant changes of C, N, P content and stoichiometric ratio in plants and soil began to appear after 7 years of alfalfa planting, indicating that the 7th year was a turning point. The C:P and N:P ratios of soil and alfalfa are positively correlated. The N:P ratio increased with the growth age of alfalfa, and it exceeded 14 in 7, 9, and 10 years, indicating that the growth of alfalfa has been severely restricted by P. Alfalfa responds to the increasing N:P ratio by increasing underground biomass and decreasing aboveground biomass, while it can improve the nutrient content and biological characteristics of the soil at the meantime. Collectively, our research combines stoichiometric characteristics with alfalfa cultivation, indicating that after 7 years of cultivation, the growth of alfalfa has seriously deteriorated, but it can significantly improve the soil fertility of $\mathrm{Mu}$ Us Desert edge area.

\section{ACKNOWLEDGMENTS}

This research is jointly supported by the National Key Research and Development Program of China (2017YFE0104500), the China Agriculture Research System (CARS-34), Shaanxi Academy of Forestry Science and Technology Innovation Program (SXLK2020-0204).

\section{AUTHOR'S CONTRIBUTION}

Professor Yang and Professor Xin carried out the conception and design of the study, Zhouchang Yu, Yuanying $\mathrm{Li}$ and Ruirui Yan conducted the entire experimental study, Wei Zhang, Yi Zhou, Zhiguo Xie and Zhouchang Yu participated in the manuscript preparation and revision,Professor Yang, Professor Xin and Zhiguo Xie provided financial support for the study.

\section{REFERENCES}

Abinandan, S., Subashchandrabose, S. R., Venkateswarlu, K., \& Megharaj, M. (2019). Soil microalgae and cyanobacteria: the biotechnological potential in the maintenance of soil fertility and health. Critical Reviews in Biotechnology, 39(8), 981-998. doi:10.1080/07388551.2019.1654972 Agren, G. I. (2004). The C : N : P 
stoichiometry of autotrophs - theory and observations. Ecology Letters, 7(3), 185-191. doi:10.1111/j.14610248.2004.00567.x Alegre, J., Alonso-Blazquez, N., de Andres, E. F., Tenorio, J. L., \& Ayerbe, L. (2004). Revegetation and reclamation of soils using wild leguminous shrubs in cold semiarid Mediterranean conditions: Litterfall and carbon and nitrogen returns under two aridity regimes. Plant and Soil, 263(1-2), 203-212. doi:Doi 10.1023/B:Plso.0000047735.73030.41 Bai, X. J., Wang, B. R., An, S. S., Zeng, Q. C., \& Zhang, H. X. (2019). Response of forest species to C:N:P in the plant-litter-soil system and stoichiometric homeostasis of plant tissues during afforestation on the Loess Plateau, China. Catena, 183. doi:UNSP 10418610.1016/j.catena.2019.104186 Barbosa, N. C., Arruda, E. M., Brod, E., \& Pereira, H. S. (2015). Vertical Distribution of Phosphorus in Soil in Function of Modes of Application. Bioscience Journal, 31(1), 87-95. Bermejo, S. P., Prado-Guerra, A., Perez, A. I. G., \& Prieto, L. F. C. (2020). Study of quinoa plant residues as a way to produce energy through thermogravimetric analysis and indexes estimation. Renewable Energy, 146, 2224-2233. doi:10.1016/j.renene.2019.08.056 Boerner, R. E. J., Brinkman, J. A., \& Smith, A. (2005). Seasonal variations in enzyme activity and organic carbon in soil of a burned and unburned hardwood forest. Soil Biology \& Biochemistry, 37(8), 1419-1426. doi:10.1016/j.soilbio.2004.12.012 Braakhekke, W. G., \& Hooftman, D. A. P. (1999). The resource balance hypothesis of plant species diversity in grassland. Journal of Vegetation Science, 10(2), 187-200. doi:Doi 10.2307/3237140 Cassagne, N., Remaury, M., Gauquelin, T., \& Fabre, A. (2000). Forms and profile distribution of soil phosphorus in alpine Inceptisols and Spodosols (Pyrenees, France). Geoderma, 95(1-2), 161-172. doi:Doi 10.1016/S0016-7061(99)00093-2 Chang, R. Y., Jin, T. T., Lu, Y. H., Liu, G. H., \& Fu, B. J. (2014). Soil Carbon and Nitrogen Changes following Afforestation of Marginal Cropland across a Precipitation Gradient in Loess Plateau of China. Plos One, 9(1). doi:ARTN e8542610.1371/journal.pone.0085426 Chen, L. L., Mu, X. M., Yuan, Z. Y., Deng, Q., Chen, Y. L., Yuan, L. Y., . . . Kallenbach, R. L. (2016). Soil nutrients and water affect the age-related fine root biomass but not production in two plantation forests on the Loess Plateau, China. Journal of Arid Environments, 135, 173-180. doi:10.1016/j.jaridenv.2016.09.003 Chen, Y.-L., Chen, L.-Y., Peng, Y.-F., Ding, J.-Z., Li, F., Yang, G.-B., . . . Yang, Y.-H. (2016). Linking microbial C:N:P stoichiometry to microbial community and abiotic factors along a 3500-km grassland transect on the Tibetan Plateau. 25(12), 14161427. doi:10.1111/geb.12500 Cui, Q., Lu, X.-T., Wang, Q.-B., \& Han, X.-G. (2010). Nitrogen fertilization and fire act independently on foliar stoichiometry in a temperate steppe. Plant and Soil, 334(1), 209-219. doi:10.1007/s11104-010-0375-5 Elser, J. J., Fagan, W. F., Kerkhoff, A. J., Swenson, N. G., \& Enquist, B. J. (2010). Biological stoichiometry of plant production: metabolism, scaling and ecological response to global change. New Phytologist, 186(3), 593-608. doi:10.1111/j.1469-8137.2010.03214.x Fan, H., Wu, J., Liu, W., Yuan, Y., Hu, L., \& Cai, Q. (2015). Linkages of plant and soil C:N:P stoichiometry and their relationships to forest growth in subtropical plantations. Plant and Soil, 392(1-2), 127-138. doi:10.1007/s11104-015-2444-2 Fan, H. B., Wu, J. P., Liu, W. F., Yuan, Y. H., Hu, L., \& Cai, Q. K. (2015). Linkages of plant and soil $\mathrm{C}: \mathrm{N}: \mathrm{P}$ stoichiometry and their relationships to forest growth in subtropical plantations. Plant and Soil, 392(1-2), 127-138. doi:10.1007/s11104-015-2444-2 Fiorini, A., Boselli, R., Maris, S. C., Santelli, S., Ardenti, F., Capra, F., \& Tabaglio, V. (2020). May conservation tillage enhance soil C and N accumulation without decreasing yield in intensive irrigated croplands? Results from an eight-year maize monoculture. Agriculture, Ecosystems \& Environment, 296. doi:10.1016/j.agee.2020.106926 Gersani, M., Brown, J. S., O’Brien, E. E., Maina, G. M., \& Abramsky, Z. (2001). Tragedy of the commons as a result of root competition. Journal of Ecology, 89(4), 660-669. doi:DOI 10.1046/j.0022-0477.2001.00609.x Griesmann, M., Chang, Y., Liu, X., Song, Y., Haberer, G., Crook, M. B., . . . Cheng, S. F. (2018). Phylogenomics reveals multiple losses of nitrogen-fixing root nodule symbiosis. Science, 361(6398). doi:ARTN eaat174310.1126/science.aat1743 Guo, J., Wang, B., Wang, G. B., Wu, Y. Q., \& Cao, F. L. (2020). Afforestation and agroforestry enhance soil nutrient status and carbon sequestration capacity in eastern China. Land Degradation \& Development, 31(3), 392-403. doi:10.1002/ldr.3457 Gusewell, S. (2004). N : P ratios in terrestrial plants: variation and functional significance. New Phytologist, 164(2), 243-266. doi:10.1111/j.1469-8137.2004.01192.x Han, W. X., Fang, J. Y., Guo, D. L., \& Zhang, Y. (2005). Leaf nitrogen and phosphorus stoichiometry across 753 terrestrial plant species in China. New Phytologist, 168(2), 377-385. doi:10.1111/j.1469-8137.2005.01530.x Hong, J. T., Wang, X. D., \& Wu, J. B. (2014). Stoichiometry of Root and Leaf Nitrogen and Phosphorus in a Dry Alpine Steppe on the Northern Tibetan Plateau. Plos One, 9(10). doi:ARTN e10905210.1371/journal.pone.0109052 
Hooker, T. D., \& Compton, J. E. (2003). Forest Ecosystem Carbon and Nitrogen Accumulation during the First Century after Agricultural Abandonment. Ecological Applications, 13(2), 299-313. doi: 10.1890/10510761(2003)013[0299:fecana]2.0.co;2 Hwangl, S., \& Flores, G. (1987). Effects of C ylindrocladium gracile, Fusarium roseum and Plenodomus melilotion crown and root rot, forage yield, and winterkill of alfalfa in north-eastern Alberta. Canadian Plant Disease Survey, 67(2), 31-33. doi:10.2307/2996389 Iqbal, M. A., Hamid, A., Ahmad, T., Siddiqui, M. H., Hussain, I., Ali, S., . . . Ahmad, Z. (2019). Forage sorghumlegumes intercropping: effect on growth, yields, nutritional quality and economic returns. Bragantia, 78(1), 82-95. doi:10.1590/1678-4499.2017363 Jacobs, S. M., Pettit, N. E., \& Naiman, R. J. (2007). Nitrogen fixation by the savanna tree Philenoptera violacea (Klotzsch) Schrire (Apple leaf) of different ages in a semi-arid riparian landscape. South African Journal of Botany, 73(1), 163-167. doi:10.1016/j.sajb.2006.09.001 Joergensen, R. G., Anderson, T. H., \& Wolters, V. (1995). Carbon and Nitrogen Relationships in the Microbial Biomass of Soils in Beech (Fagus-Sylvatica L) Forests. Biology and Fertility of Soils, 19(2-3), 141-147. doi: 10.1007/Bf00336150 Jones, D. L., Rousk, J., Edwards-Jones, G., DeLuca, T. H., \& Murphy, D. V. (2012). Biochar-mediated changes in soil quality and plant growth in a three year field trial. Soil Biology \& Biochemistry, 45, 113-124. doi:10.1016/j.soilbio.2011.10.012 Kohmann, M. M., Sollenberger, L. E., Dubeux, J. C. B., Silveira, M. L., Moreno, L. S. B., da Silva, L. S., \& Aryal, P. (2018). Nitrogen Fertilization and Proportion of Legume Affect Litter Decomposition and Nutrient Return in Grass Pastures. Crop Science, 58(5), 2138-2148. doi:10.2135/cropsci2018.01.0028 Kou, L., Li, S. G., Wang, H. M., Fu, X. L., \& Dai, X. Q. (2019). Unaltered phenology but increased production of ectomycorrhizal roots of Pinus elliottii under 4 years of nitrogen addition. New Phytologist, 221(4), 2228-2238. doi:10.1111/nph.15542 Kubar, K. A., Huang, L., Lu, J. W., Li, X. K., Xue, B., \& Yin, Z. Y. (2019). Long-term tillage and straw returning effects on organic $\mathrm{C}$ fractions and chemical composition of SOC in rice-rape cropping system. Archives of Agronomy and Soil Science, 65(1), 125-137. doi:10.1080/03650340.2018.1490726 Laird, R. A., \& Aarssen, L. W. (2005). Size inequality and the tragedy of the commons phenomenon in plant competition. Plant Ecology, 179(1), 127-131. doi:10.1007/s11258-004-6737-4 LeBauer, D. S., \& Treseder, K. K. (2008). Nitrogen limitation of net primary productivity in terrestrial ecosystems is globally distributed. Ecology, 89(2), 371-379. doi: 10.1890/06-2057.1 Li, D. C., Velde, B., Li, F. M., Zhang, G. L., Zhao, M. S., \& Huang, L. M. (2011). Impact of Long-Term Alfalfa Cropping on Soil Potassium Content and Clay Minerals in a Semi-Arid Loess Soil in China. Pedosphere, 21(4), 522-531. doi: 10.1016/S1002-0160(11)60154-9 Li, S., Li, X. S., Zhu, W. L., Chen, J., Tian, X. H., \& Shi, J. L. (2019). Does Straw Return Strategy Influence Soil Carbon Sequestration and Labile Fractions? Agronomy Journal, 111(2), 897-906. doi:10.2134/agronj2018.08.0484 Li, Z. G., Zhang, R. H., Liu, C., Zhang, R. Q., Chen, F., \& Liu, Y. (2020). Phosphorus spatial distribution and pollution risk assessment in agricultural soil around the Danjiangkou reservoir, China. Science of the Total Environment, 699. doi:ARTN 13441710.1016/j.scitotenv.2019.134417 Liao, Y. C., McCormack, M. L., Fan, H. B., Wang, H. M., Wu, J. P., Tu, J., . . . Guo, D. L. (2014). Relation of fine root distribution to soil C in a Cunninghamia lanceolata plantation in subtropical China. Plant and Soil, 381(1-2), 225-234. doi:10.1007/s11104-0142114-9 Liu, J. X., Liu, G. B., Flanagan, D. C., Wang, B., Wang, Z. Y., \& Xiao, J. (2020). Effects of soil-incorporated plant litter morphological characteristics on the soil detachment process in grassland on the Loess Plateau of China. Sci Total Environ, 705, 134651. doi:10.1016/j.scitotenv.2019.134651 Lu, J. Y., Yang, M., Liu, M. G., Wang, Y. Y., \& Yang, H. M. (2019). Leaf stoichiometry and resorption of N and P in Lucerne at different growth stages under different water supplies. Journal of Plant Nutrition, 42(5), 501-511. doi:10.1080/01904167.2019.1567776 Lynd, J. Q., \& Ansman, T. R. (1993). Symbiotic Tripartite NitrogenFixation Effectual in Eroded Soil Restoration with 20 Year-Age Sericea-Lespedeza. Journal of Plant Nutrition, 16(1), 149-164. doi:10.1080/01904169309364519 Ma, S. C., Li, F. M., Xu, B. C., \& Huang, Z. B. (2010). Effect of lowering the root/shoot ratio by pruning roots on water use efficiency and grain yield of winter wheat. Field Crops Research, 115(2), 158-164. doi:10.1016/j.fcr.2009.10.017 Maina, G. G., Brown, J. S., \& Gersani, M. (2002). Intra-plant versus inter-plant root competition in beans: avoidance, resource matching or tragedy of the commons. Plant Ecology, 160(2), 235-247. doi: 10.1023/A:1015822003011 Masikane, S. L., Novela, P., Mohale, P., \& McLeod, A. (2020). Effect of phosphonate application timing and -strategy on phosphite fruit and root residues of avocado. Crop Protection, 128. doi:ARTN 10500810.1016/j.cropro.2019.105008 McGroddy, M. E., Daufresne, T., \& Hedin, L. O. (2004). Scaling of C : N : P stoichiometry in forests 
worldwide: Implications of terrestrial redfield-type ratios. Ecology, 85(9), 2390-2401. doi: 10.1890/03-0351 McGroddy, M. E., Daufresne, T., \& Hedin, L. O. (2004). Scaling of C:N:P Stoichiometry in Forests Worldwide: Implications of Terrestrial Redfield-Type Ratios. Ecology, 85(9), 2390-2401. doi: 10.1890/03-0351 McGroddy, M. E., Daufresne, T., \& Hedin, L. O. (2008). Scaling of C : N : P stoichiometry in forests worldwide: implications of terrestrial Redfield-type ratios (vol 85, pg 2390, 2004). Ecology, 89(3), 890-890. doi: 10.1890/03-0351 McKenzie, J., \& McLean, G. (1984). A FIELD TEST FOR ASSESSING THE WINTER HARDINESS OF ALFALFA IN NORTHWESTERN CANADA. Canadian Journal of Plant Science - CAN J PLANT SCI, 64, 917-924. doi:10.4141/cjps84-125 Oo, A. Z., Win, K. T., Basalirwa, D., Gonai, T., \& Sudo, S. (2020). Autumn Leaf Litter and Its Biochar Amendment on Soil Nitrous Oxide Emission, Plant Growth, and Nutrient Uptake of Komatsuna and Spinach Grown in Potted Soils. Journal of Agricultural Science, 12(2). doi:10.5539/jas.v12n2p26 Paul, K. I., Polglase, P. J., Nyakuengama, J. G., \& Khanna, P. K. (2002). Change in soil carbon following afforestation. Forest Ecology and Management, 168(1-3), 241-257. doi 10.1016/S0378-1127(01)00740-X Paul, K. L., Polglase, P. J., \& Richards, G. P. (2003). Predicted change in soil carbon following afforestation or reforestation, and analysis of controlling factors by linking a $\mathrm{C}$ accounting model (CAMFor) to models of forest growth (3PG), litter decomposition (GENDEC) and soil C turnover (RothC). Forest Ecology and Management, 177(1-3), 485-501. doi 10.1016/S0378-1127(02)00454-1 Reich, P. B., \& Oleksyn, J. (2004a). Global patterns of plant leaf N and P in relation to temperature and latitude. Proc Natl Acad Sci U S A, 101(30), 11001-11006. doi:10.1073/pnas.0403588101 Reich, P. B., \& Oleksyn, J. (2004b). Global patterns of plant leaf $\mathrm{N}$ and $\mathrm{P}$ in relation to temperature and latitude. Proceedings of the National Academy of Sciences of the United States of America, 101(30), 11001-11006. doi:10.1073/pnas.0403588101 Reich, P. B., Oleksyn, J., \& Tilman, G. D. (2004). Global Patterns of Plant Leaf $\mathrm{N}$ and $\mathrm{P}$ in Relation to Temperature and Latitude. Proceedings of the National Academy of Sciences of the United States of America, 101(30), 11001-11006. doi: 10.1073/pnas.0403588101 Ren, C. J., Zhao, F. Z., Kang, D., Yang, G. H., Han, X. H., Tong, X. G., . . . Ren, G. X. (2016). Linkages of $\mathrm{C}: \mathrm{N}: \mathrm{P}$ stoichiometry and bacterial community in soil following afforestation of former farmland. Forest Ecology and Management, 376, 59-66. doi:10.1016/j.foreco.2016.06.004 Sardans, J., Rivas-Ubach, A., \& Penuelas, J. (2011). Factors affecting nutrient concentration and stoichiometry of forest trees in Catalonia (NE Spain). Forest Ecology and Management, 262(11), 2024-2034. doi:10.1016/j.foreco.2011.08.019 Sardans, J., Rivas-Ubach, A., \& Penuelas, J. (2011). Factors affecting nutrient concentration and stoichiometry of forest trees in Catalonia (NE Spain). Forest Ecology and Management, 262(11), 2024-2034. doi:https://doi.org/10.1016/j.foreco.2011.08.019 Schindler, D. W. (2003). Ecological stoichiometry: The biology of elements from molecules to the biosphere. Nature, 423(6937), 225-226. doi:10.1038/423225b Sohrt, J., Herschbach, C., \& Weiler, M. (2018). Foliar P- but not N resorption efficiency depends on the P-concentration and the N:P ratio in trees of temperate forests. Trees-Structure and Function, 32(5), 14431455. doi:10.1007/s00468-018-1725-9 Song, Z. P., Liu, Y. H., Su, H. X., \& Hou, J. H. (2020). N-P utilization of Acer mono leaves at different life history stages across altitudinal gradients. Ecology and Evolution, 10(2), 851-862. doi:10.1002/ece3.5945 Vesterdal, L., Ritter, E., \& Gundersen, P. (2002). Change in soil organic carbon following afforestation of former arable land. Forest Ecology and Management, 169(1-2), 137-147. doi 10.1016/S0378-1127(02)00304-3 Vezzani, F. M., Anderson, C., Meenken, E., Gillespie, R., Peterson, M., \& Beare, M. H. (2018). The importance of plants to development and maintenance of soil structure, microbial communities and ecosystem functions. Soil \& Tillage Research, 175, 139-149. doi:10.1016/j.still.2017.09.002 Wang, H. H., Li, X., Li, X., Wang, J., Li, X. Y., Guo, Q. C., . . . Zhang, H. W. (2020). Long-term no-tillage and different residue amounts alter soil microbial community composition and increase the risk of maize root rot in northeast China. Soil \& Tillage Research, 196. doi:ARTN 10445210.1016/j.still.2019.104452 Wang, Z., Lu, J., Yang, H., Zhang, X., Luo, C., \& Zhao, Y. (2014). Resorption of nitrogen, phosphorus and potassium from leaves of lucerne stands of different ages. Plant and Soil, 383(1), 301-312. doi:10.1007/s11104-014-2166x Wang, Z. F., \& Zheng, F. L. (2020). Impact of vegetation succession on leaf-litter-soil C:N:P stoichiometry and their intrinsic relationship in the Ziwuling Area of China's Loess Plateau. Journal of Forestry Research. doi:10.1007/s11676-020-01149-z Wang, Z. N., Lu, J. Y., Yang, M., Yang, H. M., \& Zhang, Q. P. (2015). Stoichiometric Characteristics of Carbon, Nitrogen, and Phosphorus in Leaves of Differently Aged Lucerne (Medicago sativa) Stands. Frontiers in Plant Science, 6. doi: 10.3389/fpls.2015.01062 Xiao, L., Huang, Y. 
M., Zeng, Q. C., Zhao, J. F., \& Zhou, J. Y. (2018). Soil enzyme activities and microbial biomass response to crop types on the terraces of the Loess Plateau, China. Journal of Soils and Sediments, 18(5), 1971-1980. doi:10.1007/s11368-018-1969-4 Xie, J., Yan, Q. L., Yuan, J. F., Li, R., Lu, X. T., Liu, S. L., \& Zhu, J. J. (2020). Temporal Effects of Thinning on the Leaf C:N:P Stoichiometry of Regenerated Broadleaved Trees in Larch Plantations. Forests, 11(1). doi:ARTN 5410.3390/f11010054 Yang, H. M., Unkovich, M., McNeill, A., \& Wang, X. Z. (2011). Symbiotic N-2 fixation and nitrate utilisation in irrigated lucerne (Medicago sativa) systems. Biology and Fertility of Soils, 47(4), 377-385. doi:10.1007/s00374-011-0543-7 Yang, Y., Liu, B. R., \& An, S. S. (2018). Ecological stoichiometry in leaves, roots, litters and soil among different plant communities in a desertified region of Northern China. Catena, 166, 328-338. doi:10.1016/j.catena.2018.04.018 Yang, Y., \& Luo, Y. (2011). Carbon : nitrogen stoichiometry in forest ecosystems during stand development. Global Ecology and Biogeography, 20(2), 354-361. doi:10.1111/j.1466-8238.2010.00602.x Yang, Y., \& Luo, Y. (2011). Carbon : nitrogen stoichiometry in forest ecosystems during stand development. Global Ecology and Biogeography, 20(2), 354-361. doi:10.1111/j.1466-8238.2010.00602.x Yang, Y. H., Luo, Y. Q., Lu, M., Schadel, C., \& Han, W. X. (2011). Terrestrial C:N stoichiometry in response to elevated CO2 and N addition: a synthesis of two meta-analyses. Plant and Soil, 343(1-2), 393-400. doi:10.1007/s11104-011-0736-8 Zhang, W., Liu, W., Xu, M., Deng, J., Han, X., Yang, G., Ren, G. (2019). Response of forest growth to $\mathrm{C}: \mathrm{N}: \mathrm{P}$ stoichiometry in plants and soils during Robinia pseudoacacia afforestation on the Loess Plateau, China. Geoderma, 337, 280-289. doi:https://doi.org/10.1016/j.geoderma.2018.09.042 Zhang, X., Wang, Z., \& Yang, H. M. (2013). Soil nitrogen, phosphorus and potassium: which is the bottleneck element during lucerne growth? Proceedings of the 4th International Symposium for Farming Systems Design,Lanzhou, 19-22. Zhen, L. S., Gu, J., Hu, T., \& Chen, Z. X. (2018). Effects of compost containing oxytetracycline on enzyme activities and microbial communities in maize rhizosphere soil. Environmental Science and Pollution Research, 25(29), 29459-29467. doi:10.1007/s11356-018-2964-4 Zhiyanski, M., Glushkova, M., Ferezliev, A., Menichetti, L., \& Leifeld, J. (2016). Carbon storage and soil property changes following afforestation in mountain ecosystems of the Western Rhodopes, Bulgaria. Iforest-Biogeosciences and Forestry, 9, 626-634. doi:10.3832/ifor1866-008

\section{Hosted file}

Tables.docx available at https://authorea.com/users/351721/articles/476233-response-ofbiomass-allocation-strategies-to-plant-soil-c-n-p-stoichiometry-in-alfalfa-artificialgrassland-of-different-ages-on-the-mu-us-desert-china

\section{Hosted file}

Figures.docx available at https://authorea.com/users/351721/articles/476233-response-ofbiomass-allocation-strategies-to-plant-soil-c-n-p-stoichiometry-in-alfalfa-artificialgrassland-of-different-ages-on-the-mu-us-desert-china

\section{Hosted file}

Cover letter. docx available at https://authorea.com/users/351721/articles/476233-response-ofbiomass-allocation-strategies-to-plant-soil-c-n-p-stoichiometry-in-alfalfa-artificialgrassland-of-different-ages-on-the-mu-us-desert-china

\section{Hosted file}

Highlights.docx available at https://authorea.com/users/351721/articles/476233-response-ofbiomass-allocation-strategies-to-plant-soil-c-n-p-stoichiometry-in-alfalfa-artificialgrassland-of-different-ages-on-the-mu-us-desert-china

\section{Hosted file}

Declaration of interest.docx available at https://authorea.com/users/351721/articles/476233response-of-biomass-allocation-strategies-to-plant-soil-c-n-p-stoichiometry-in-alfalfaartificial-grassland-of-different-ages-on-the-mu-us-desert-china 